Adegbite, T.A. (2019). An evaluation of the effect of taxation policy on inflation in Nigeria. Copernican Journal of Finance \& Accounting, 8(2), 7-23. http://dx.doi.org/10.12775/CJFA.2019.006

\author{
Tajudeen Adejare Adegbite* \\ Al-Hikmah University
}

\title{
AN EVALUATION OF THE EFFECT OF TAXATION POLICY ON INFLATION IN NIGERIA
}

Keywords: taxation, inflation in Nigeria, petroleum profit tax (PPT), value added tax (VAT), corporate income tax, custom and excise duties, co-integration.

J E L Classification: 023, E31, C1.

\begin{abstract}
Taxation is one of the instruments of fiscal policy employed by developing countries to fight inflation. Taxation as a field of study has grown with many contributions from different fields. The gap within the literature regarding different contexts has inspired researchers to look for further explanations about taxation and its effects on inflation. Therefore, this paper aims to provide insight into the effects of taxation policy on inflation in Nigeria. To achieve this, a quantitative research is carried out. Empirical test indicates that taxation had negative significant effect on inflation both in the short run and in the long run. All the components of taxation did not Granger-cause inflation in Nigeria. Additionally, according to the results, taxation is an effective hedge against inflation in the country.
\end{abstract}

\section{INTRODUCTION}

Maintenance of price stability continues to be dominant objective of fiscal policy for most countries in the world today especially developing country like

Date of submission: July 5, 2019; date of acceptance: July 25, 2019.

* Contact information: adetajud@yahoo.com, Al-Hikmah University, Ilorin, Kwara State, Nigeria, phone: +2348035793148; ORCID ID: https://orcid.org/0000-0001-74560172 . 
Nigeria. This perhaps showed the prominence given to price stability in conduct of fiscal policy with the disposition and mindset of promoting sustainable growth and development as well as strengthening the purchasing power of the domestic currency amongst others. Nigeria government employs taxation targeting framework in the conduct of its fiscal policy. This is based on the assumption of a stable and predictable relationship between taxation and inflation. Taxation as a fiscal tool available to the government can be used to fight inflation and its undesirable trends (Caesar, 2013). Taxes have an important place in their programs and they are a powerful tool for achieving main goals in the economy.

According to Caesar (2013), an increase in the rate of taxes during inflationary period can reduce expenditure from the private sector thereby reducing pressure on the market and curtailing inflation. In Keynesian economics framework, taxes are determinants of aggregate demand. So, increases in taxes lead to lesser demand (as consumers will have less money to spend) and, hence, their impact tend to be deflationary. Similarly, it can be argued that tax cuts lead to more consumers spending and their impact tend to be inflationary. But aggregate supply remains completely unaffected by changes in taxes. On the other hand, those who discarded the above framework believe that from a supply side perspective, increases in taxes tend to increase the production cost and the burden is passed on from the producers to the consumers in the form of indirect taxes. So, the prices of goods and services will rise leading to inflation. With this divergent outlooks, this study examined the effect of taxation on inflation in Nigeria. Based on the objective of the study, the following hypotheses were tested:

$\mathrm{Ho}_{1}$ : Taxation has no significant effect on inflation in Nigeria.

$\mathrm{Ho}_{2}$ : Taxation has no long run effect on inflation in Nigeria.

$\mathrm{Ho}_{3}$ : Taxation has no causality with inflation in Nigeria.

\section{LITERATURE REVIEW AND THEORETICAL FRAME WORK}

\section{Concept of Inflation and Taxation}

Inflation has been defined as a persistence rise in the general price level of broad spectrum of goods and services in a country over a long period of time. It has been widely described as an economic situation when the increase in money supply is faster than the new production of goods and services in the same 
economy (Piana, 2001). According to 0jo (2000), inflation as general and persistent increase in the prices of goods and services in an economy. Inflation rate is measured as the percentage change in the price index (consumer price index, wholesale price index, producer price index etc).

There are three major types of inflation according to neo-Keynesians. The first is the demand-pull inflation, which occurs when aggregate demand is in excess of available supply (capacity). This phenomenon is also known as the Phillips curve inflation. The output gap can result from an increase in government purchases, increase in foreign price level, or increase in money supply. The second is known as cost-push inflation, which is referred to inflation which occurs in the event of a sudden decrease in aggregate supply, owing to an increase in the price/cost of the commodity/production where there are no suitable alternatives (Thomas, 2006). This type of inflation is becoming more common today than before, as evident in the rising price of housing, energy and food. It is often reflected in price/wage spirals in firms, whereby workers try to keep up their wages with the change in the price level and employers pass on the burden of higher costs to consumers through increase in prices. The third type, referred to, as structural inflation, which is built-in inflation, usually induced by changes in monetary policy.

Taxation is a system by which government imposed a compulsory levy on individuals, companies, goods and services to raise revenue for its operations, to control inflation, and to promote social equity through the redistribution of income effect of taxation. In addition, Bhartia (2009) defined tax as a compulsory levy payable by an economic unit to the government without any corresponding entitlement to receive a definite and direct benefit from the government. Note, the word direct here does not mean a price paid by the tax payer for any definite service rendered or a commodity supplied by the government. Rather it means that the benefits received by tax payers from the government are not related to or based upon the tax paid by the tax payers. This in effect implies that tax is a generalized exaction, which may be levied on one or more criteria upon individuals, groups, or the legal entities.

Adegbite and Usman (2017) opined that government employs taxation to steer the economy in a desired direction. If the government wishes to stimulate the economy, government implement it by cutting taxes. A tax cut enhances the disposable income of the individual. This simple policy prescription of reducing taxes will increase spending, making production to go up and creating employment which will invariably leads to increment in tax revenue. If the 
government wishes to restrain the economy, it could do so by increasing taxes. By so doing disposable income will fall leading to a fall in spending and production. In this case, a tax increase will shift the consumption function down by the amount of the tax and reduce the level of income by a multiplier effect. A tax cut, on the other hand, raises consumption and exerts a multiplier effect on the level of income (Iniodu, 1996). During a recession (when the economy is deflationary) government can stimulate aggregate demand by cutting taxes, which should bring about more jobs and reduce unemployment rate and deflationary gap in the economy. If the economy is inflationary, to dampen the inflationary pressure, the policy prescription is to contract the economy indirectly by raising taxes to discourage consumption.

\section{UNDERPINNING THEORY}

\section{The expediency theory}

This theory asserts that every tax proposal must pass the test of practicability. It must be the only consideration weighing with the authorities in choosing a tax proposal. Economic and social objectives of the state as also the effects of a tax system should be treated as irrelevant. This proposition has a truth in it, since it is useless to have a tax which cannot be levied and collected efficiently. There are pressures from economic, social and political groups. Every group tries to protect and promote its own interests and authorities are often forced to reshape tax structure to accommodate these pressures. In addition, the administrative set up may not be efficient to collect the tax at a reasonable cost of collection. Taxation provides a powerful set of policy tools to the authorities and should be effectively used for remedying economic and social ills of the society such as income inequalities, regional disparities, unemployment, cyclical fluctuations, inflation and so on.

\section{REVIEW OF EMPIRICAL STUDIES ON THE RELATIONSHIP BETWEEN FISCAL POLICY AND INFLATION IN NIGERIA}

Anyanwu (1997) investigated the effect of taxes on inflation and unemployment rates in Nigeria between 1981 and 1996. Using data on taxes, inflation and unemployment rates during the period of study, the results of his log-linear regression reveal a positive relationship between taxes and inflation rate, 
but with insignificant coefficient. Based on this result, he concluded that taxes fuelled Nigeria's inflation rather that reducing it. On the unemployment rate, his findings reveal that different taxes affect Nigeria's unemployment for the different period between 1981-1996. He concluded that taxes vary negatively with unemployment, and with the coefficient of unemployment being insignificant. However, the scope of this study is from 1981 to 1996 but it was not extended to 2017.

Atan (2013) examined the attempts by successive Nigerian governments to use taxation to influence macroeconomic aggregates, especially inflation and unemployment, and covers the period 1970 to 2008. It is largely a secondary data study, focusing on the extent to which these variables responded to changes in government's tax measures. Data on these variables for the thirty-nine year period were analysed using both descriptive and inferential statistical techniques. The Ordinary Least Square (OLS) method was used for the estimations. The analysis shows that the historical trends in inflation and unemployment showed no significant response to tax policy between the period 1970 and 2008. Periods of lower taxes recorded lower inflation rate in some years and higher inflation rates in some years. Unemployment rates increased steadily in some years whether taxes were raised or lowered. Government in some years lowered taxes amidst high inflation rates in the economy. Taxes have a negative effect on the inflation rate in line with the theory, but with insignificant coefficient. In the case of unemployment rate, the regression results show a negative relationship between tax policy and unemployment, but with insignificant coefficient, which is contrary to the theory. The analysis shows that tax policy was not effective in controlling inflation, and tackling unemployment problems in the economy during the period of study largely because of inconsistency in the use of tax measures. It is recommended that government apply tax measures much more carefully than was observed over the period studied. However, this study was confined to 2008, it was not expanded to 2017. Also, the study employed only Ordinary Least Square (OLS) method for the estimations. Perhaps, the results was spurious because of the failure to carry out further tests.

Olaoye (2016) examined the determinants of VAT, Interest rate, Inflation and Influence on revenue generation in Nigeria. Secondary data were gathered from CBN statistics bulletins that cutacross 1990 and 2012. This period was selected in order to capture the inflation, Interest rate, prior, during and post implementation of VAT. Data were analyzed with the use of descriptive analysis and Johansen co-integration test. The descriptive statistics gave a clear picture 
of the distribution and range of all the series, there exist no significant relationship between VAT and INT. However, there is significant positive relationship between VAT \& INF both on the short and long run, while interest rate exert negative influence on Inflation both on the short and long run. There is strong and positive relationship between VAT and revenue generation in Nigeria. It was recommended that government should provide effective anti-inflationary policy to cushion the inflationary tendencies of value added tax in the country and regulate the rise in the level of interest rate in order not provoke price instability and at the same time maintain the current level of improvement in the revenue generation in the country. This study used only a single component of taxation (VAT) to generalize the effect of taxation on inflation rate with restricted scope of 2012.

Akhor, Atu and Ekundayo (2016) examined the impact of indirect tax revenue on economic growth in Nigeria. The study used value added tax revenue and custom and excise duty revenue as independent variables and economic growth was proxy with real gross domestic product as the dependent variable. The study employ secondary data collected from Central Bank of Nigeria statistical bulletin for the period covering 1993 to 2013 for the empirical analysis using the convenient sampling techniques. The data were analyzed using descriptive statistics, correlation, unit root test, cointegration test and error correction model regression. The result revealed that value added tax had a negative and significant impact on real gross domestic product. In the same vein, past custom and excise duty had a negative and weakly significant impact on real gross domestic product. The Error Correction Model (ECM (-1)) coefficient had a correct negative and statistically significant sign. This shows that shortrun deviation can be quickly corrected. The Durbin-Watson positive value indicates the absence of autocorrelation in the model. The study recommended that tax administrative loopholes should be plugged for tax revenue to contribute immensely to the development of the economy since past value added tax and custom and excise duty had a significant impact on economic growth. However, this study was restricted to the effect of indirect taxes on revenue generation but the scope was not stretched to inflation.

From the review of previous works, the gaps identified are scope, methodology and conceptual gap. This is because all the studies seen and reviewed are conducted in Nigeria with different scope, methodology and concepts, and the findings may not be generalized in wider perspectives. Thus, this study is 
unique and intends to contribute to knowledge by investigating the effect of taxation on inflation in Nigeria.

\section{THE RESEARCH METHODOLOGY AND THE COURSE OF THE RESEARCH PROCESS}

Secondary data were used in this study. The relevant data for the study were obtained from Central Bank of Nigeria (CBN) Statistical Bulletins and Federal Inland Revenue Services Bulletin from 1970 to 2017. Regression analysis technique was used to measure the effects of independent variables on dependent variable while Units root test, Johansen co-integration, Vector Error-Correction Model, and Granger causality tests were employed to determine the long run relationship and causality links among the variables.

\section{Model Specification}

Nigeria's inflation rate has been increasing persistently for years now, and even exceeded 16 percent in 2017, and a real significant decrease is nowhere in sight. The bigger problem is its unsteadiness, however, an inflation rate that is active in Nigeria is usually a sign of a struggling economy, causing prices to fluctuate, and unemployment and poverty to increase. The formulation of the model was based on theory that taxation is an effective hedge against inflation, that is taxation and inflation are inversely related. Inflation (INFL) was employed as the explained variable while the explanatory variables are petroleum profit tax (PPT), Value added tax (VAT), corporate income tax (CORPT), and Custom and Excise duties (CUSEXC). This can be specifically stated as:

$$
Y=f(m 1, m 2, m 3, m 4, \mu)
$$

The independent variable $m 1-m 4$

The dependent variable $Y$

A regression model relates $Y$ to a function $m$ of and $\mu$

Error term is denoted as $\mu$.

$$
\sum_{i=1}^{n} I N F L=a 0+\sum_{i=1}^{n} a 1 P P T+\sum_{i=1}^{n} a 2 V A T+\sum_{i=1}^{n} a 3 C O R P T+\sum_{i=1}^{n} a 4 C U S E X C+\mu 3
$$


Transforming equation (1) to the natural logarithm it changed to $\sum_{i=1}^{n}$ LOGINFL $=a 0+\sum_{i=1}^{n} a 1 L O G P P T+\sum_{i=1}^{n} a 2 L O G V A T+\sum_{i=1}^{n} a 3 L O G C O R P T+\sum_{i=1}^{n} a 4 L O G C U S E X C+\mu 4$

Basic VECM is

$$
\Delta y_{t}=\propto \beta^{\prime} y_{t-1}+\sum_{t=1}^{p-1} \Gamma_{i} \Delta y_{t-i}+\epsilon_{t}
$$

where $\mathrm{y}$ is a (Kx 1) vector of I(1) variables, $\alpha$ and $\beta$ are (Kx r) parameter matrices with rank $\mathrm{r}<\mathrm{K}, \Gamma_{1}, \ldots, \Gamma_{\mathrm{p}-1}$ are $(\mathrm{K} \mathrm{x} \mathrm{K})$ matrices of parameters, and $\varepsilon \mathrm{t}$ is a (K x1) vector of normally distributed errors that is serially uncorrelated but has contemporaneous covariance matrix.

\section{RESULTS AND DISCUSSION}

Table 1. The Effect of Taxation on inflation rate in Nigeria

\begin{tabular}{|c|c|c|c|c|c|c|c|}
\hline $\begin{array}{l}\text { Dependent } \\
\text { variable }\end{array}$ & $\begin{array}{l}\text { Independent } \\
\text { variables }\end{array}$ & Coefficient & Standard error & $\mathbf{T}$ & $\mathrm{P}>/ \mathrm{T} /$ & \multicolumn{2}{|c|}{$\begin{array}{c}(95 \% \\
\text { conf. Interval) }\end{array}$} \\
\hline \multirow{5}{*}{ LOGINFL } & LOGPPT & -.2007604 & .1912754 & -4.28 & 0.005 & -.6084542 & .2069334 \\
\hline & LOGVAT & -.0947098 & .5096113 & -3.19 & 0.013 & -1.180921 & .9915011 \\
\hline & LOGCORPT & -.3071204 & .1554908 & -2.98 & 0.016 & -.6385412 & .0243004 \\
\hline & LOGCUSEXC & .5022426 & .6038969 & -3.59 & 0.008 & -.7849331 & 1.789418 \\
\hline & CONSTANT & 4.18516 & 2.212975 & 8.89 & 0.000 & -.5316856 & 8.902005 \\
\hline $\begin{array}{l}\text { R-squared } \\
=0.3665\end{array}$ & $\begin{array}{l}\text { Adj R-squared } \\
=0.2975\end{array}$ & Prob $>F=0.1222$ & \multicolumn{2}{|l|}{ Root MSE $=.58681$} & \multicolumn{3}{|c|}{$F(4,15)=2.17$} \\
\hline
\end{tabular}

S o u r c e : author's computation (2018).

The table 1 shows the effect of taxation on inflation rate in Nigeria. $1 \%$ increase in the Petroleum profit tax (PPT) reduces inflation rate (INFL) by $0.2 \%$. This suggests a negative significant effect the rate of PPT on INFL. The outcome is significant $(\beta=-.2007604, t=-4.28, P>|t|=0.005)$. One percent increase in Val- 
ue added tax (VAT) also reduces INFL by $0.09 \%$.This means VAT imparted INFL negatively and significantly $(\beta=-.0947098, t=-3.19, P>|t|=0.013)$. That is if VAT increases INFL reduces. More so, $1 \%$ increase in the corporate income tax (CORPT) reduces INFL by $0.3 \%$. This suggests a negative significant effect CORPT on INFL ( $\beta=-.3071204, t=-2.98, P>|t|=0.016)$. Contrarily, $1 \%$ increase in Custom and excise duty (CUSEXC) increases INFL by $0.5 \%$. This reveals a positive significant effect of CUSEXC on INFL ( $\beta=.5022426, t=-3.59, P>|t|=0.008)$. This is suggesting that if CUSEXC in Nigeria increases, INFL also increase.

The $\mathrm{R}^{2}$ coefficient $(0.3665)$ which is the coefficient of determination indicates that the Explanatory variables accounted for $36.7 \%$ of the variation in the influence of taxation on inflation rate in Nigeria for the period under study. Given the adjusted $\mathrm{R}^{2}$ of $29.75 \%$ which significant, it predicts the independence variables incorporated into this model have been able to determine variation of taxation on inflation rate to $29.75 \%$. It is also indicates that taxation accounted for $29.75 \%$ of the variation in the influence on inflation rate in the short-run. This hypothesis is to test whether or not there is significant effect of taxation on Inflation rate in Nigeria. From the decision rule above, because the p-value for the alternative hypothesis equals 0.0000 which is less than 0.05 , therefore the null hypothesis is rejected while the alternative hypothesis is upheld. Therefore taxation has significant effect on Inflation rate in Nigeria. Taxation is effective hedge against inflation.

Table 2. Unit Root Test

\begin{tabular}{|l|l|c|c|c|c|c|}
\hline \hline Variables & ADF stat & $\begin{array}{c}\mathbf{1 \%} \\
\text { critical value }\end{array}$ & $\begin{array}{c}\mathbf{5 \%} \\
\text { critical value }\end{array}$ & $\begin{array}{c}\mathbf{1 0 \%} \\
\text { critical value }\end{array}$ & $\begin{array}{c}\text { Order } \\
\text { of integration }\end{array}$ & Remark \\
\hline \hline INFL & 3.306 & -3.628 & -2.950 & -2.608 & $\mathrm{I}(0)$ & Stationary \\
\hline PPT & $3.892 * * *$ & -3.655 & -2.961 & -2.613 & $\mathrm{I}(1)$ & Stationary \\
\hline VAT & $4.703 * * *$ & 3.750 & 3.000 & -2.630 & $\mathrm{I}(1)$ & Stationary \\
\hline CORPT & $3.520 * * *$ & -3.655 & -2.961 & -2.613 & $\mathrm{I}(1)$ & Stationary \\
\hline CUSEXC & 2.681 & 3.750 & 3.000 & -2.630 & $\mathrm{I}(1)$ & Stationary \\
\hline \hline
\end{tabular}

$\left({ }^{*}\right),\left({ }^{* *}\right)$ and $\left({ }^{* * *}\right)$ means stationary at $1 \%, 5 \%$ and $10 \%$ respectively.

S o u r c e : author's computation (2018).

It has been a common practice, in applied econometric analysis, to test the order of integration of time series. The study applies ADF unit root test, at level and at the first difference of the time series with assumption of no drift and 
tend, to have the information about the order of a time series. ADF test results reported in the table 2 are evident that we are unable to reject the null hypothesis for the presence of a unit root at level of each of the time series. All of the time series are stationary at their first difference. Since each of the time series is stationary at its first difference so the variables are cointegrated. There exists an equilibrium or long run relationship between the time series if all the variables are integrated of the same order, Engle and Granger (1987). The study applies Johansen cointegration technique. Johansen (1991) introduced, in the multivariate cointegration test, the two likelihood ratio tests (Maximumeigen value and Trace tests) to find out the number of cointegrating vectors. All the variables are stationary at first level which exhibited that there is long run relationship between taxation and inflation in Nigeria.

Table 3. Selection-Order Criteria

\begin{tabular}{|c|c|c|c|c|c|c|c|c|}
\hline \hline Lag & LL & LR & Df & P & FPE & AIC & HQIC & SBIC \\
\hline \hline 0 & -2407.75 & & & & $1.7 e+46$ & 120.638 & 120.714 & 120.849 \\
\hline 1 & -2312.99 & 189.52 & 25 & 0.000 & $5.2 e+44$ & 117.149 & 117.607 & 118.416 \\
\hline 2 & -2239.1 & 147.78 & 25 & 0.000 & $4.8 \mathrm{e}+43$ & 114.705 & 115.545 & 117.027 \\
\hline 3 & -2130.14 & 217.92 & 25 & 0.000 & $8.6 e+41$ & 110.507 & 111.728 & 113.885 \\
\hline 4 & -1888.59 & $483.1^{*}$ & 25 & 0.000 & $2.4 \mathrm{e}+37^{*}$ & $99.6795^{*}$ & $101.282^{*}$ & $104.113^{*}$ \\
\hline \hline
\end{tabular}

Endogenous: INFL, PP, VAT, CIT, CUSEXC.

Exogenous:_cons.

S o u r c e : author's computation (2018).

The Hannan-Quinn information criterion (HQIC) method, Schwarz Bayesian information criterion (SBIC) method, and sequential likelihood-ratio (LR) test all chose four lags, as indicated by the "*" in the output. Both the SBIC and the HQIC estimators suggest that there are four cointegrating equations in the balanced-growth data. Having determined that there is a cointegrating equation among the INFL, PPT, VAT, CORPT and CUSEXC series, the parameters of a bivariate cointegrating VECM for these four series by using Vector error-correction model were estimated table 3. Lags four was used for this bivariate model because the Hannan-Quinn information criterion (HQIC)method, Schwarz Bayesian information criterion (SBIC) method, and sequential likelihood-ratio (LR) test all chose four lags, as indicated by the "*" in the output. 
Table 4. Vector Autoregression

\begin{tabular}{|l|c|c|c|c|c|}
\hline \hline \multicolumn{1}{|c|}{ Equation } & Parms & RMSE & R sq & chi2 & P>chi2 \\
\hline \hline INFL & 21 & 16.3943 & 0.4947 & 39.16547 & 0.0064 \\
\hline PPT & 21 & 45422 & 0.9994 & 68778.43 & 0.0000 \\
\hline VAT & 21 & 42103.2 & 0.9997 & 130225.6 & 0.0000 \\
\hline CORPT & 21 & 53761.7 & 0.9996 & 110487.3 & 0.0000 \\
\hline CUSEXC & 21 & 28131.5 & 0.9997 & 128997.3 & 0.0000 \\
\hline $\begin{array}{l}\text { Log likelihood }= \\
-1888.591\end{array}$ & $\begin{array}{c}\text { Det(Sigma_ml) } \\
=7.04 \mathrm{e}+34\end{array}$ & AIC $=99.67953$ & HQIC $=101.2825$ & \multicolumn{2}{c|}{ SBIC $=104.1128$} \\
\hline \hline
\end{tabular}

S o u r c e : author's computation (2018).

In order to confirm the output result of Selection-order criteria in selecting the appropriate Lag, Vector Autoregression was also tested. Lags four was also chosen for this model because the Hannan-Quinn information criterion (HQIC) method, Schwarz Bayesian information criterion (SBIC) method, and sequential likelihood-ratio (LR) test all confirmed four lags as indicated by in the table 4 above.

Table 5. Vector Error-Correction Model

\begin{tabular}{|l|c|c|c|c|c|}
\hline \hline \multicolumn{1}{|c|}{ Equation } & Parms & RMSE & R sq & chi2 & P>chi2 \\
\hline \hline D_INFL & 7 & 15.9068 & 0.0048 & .1688344 & 1.0000 \\
\hline D_PPT & 7 & 457863 & 0.3381 & 17.87596 & 0.0125 \\
\hline D_VAT & 7 & 587331 & 0.7180 & 89.09794 & 0.0000 \\
\hline D_CORPT & 7 & 673077 & 0.7466 & 103.1216 & 0.0000 \\
\hline D_CUSEXC & 7 & 399804 & 0.7072 & 84.53813 & 0.0000 \\
\hline $\begin{array}{l}\text { Log likelihood } \\
=-2387.262\end{array}$ & $\begin{array}{c}\text { Det(Sigma_ml) } \\
=1.61 e+43\end{array}$ & AIC = 115.5363 & HQIC $=116.1277$ & SBIC $=117.1498$ \\
\hline
\end{tabular}

S o u r c e : author's computation (2018). 
Table 6. Johansen normalization restriction imposed

\begin{tabular}{|l|c|c|c|c|c|}
\hline \hline \multicolumn{1}{|c|}{ Beta } & Coefficient & Std Error & Z & P>|z| & [95\% Conf. Interval] \\
\hline \hline $\begin{array}{l}\text { INF1 } \\
\text { INFL }\end{array}$ & 1 &. &. &. & \\
\hline PPT & -.000014 & .0000262 & -5.53 & 0.000 & -.0000654 .0000374 \\
\hline VAT & -.0005395 & .0001129 & -4.78 & 0.000 & $-.0007607-.0003182$ \\
\hline CORPT & -.0003488 & .0000466 & 7.49 & 0.000 & .0002575 .0004401 \\
\hline CUSEXC & -.0005504 & .0002383 & -2.31 & 0.021 & $-.0010174-.0000833$ \\
\hline -CONS & -9.071605 &. &. &. & \\
\hline \hline
\end{tabular}

S o u r c e : author's computation (2018).

Table 5 and table 6 contained information about the sample, the fit of each equation, and overall model fit statistics. The first estimation table contains the estimates of the short-run parameters, along with their standard errors, $\mathrm{z}$ statistics, and confidence intervals. The three coefficients on L. ce1 are the parameters in the adjustment matrix for this model. The second estimation table contains the estimated parameters of the cointegrating vector for this model, along with their standard errors, $\mathrm{z}$ statistics, and confidence intervals. According to Johansen normalization restriction imposed table, one percent increase in PPT reduces INFL by $0.00014 \%$ in the long run, this shows that there is a negative effect of PPT on INFL. Also, one percent increase in VAT reduces INFL by $-.0005395 \%$ in the long run, this also shows a negative effect of VAT on INFL in the long run. In the same vein, one percent increase in CORPT, reduces INFL by $-.0003488 \%$ in the long run, this also shows that there is a negative significant effect of PPT on INFL in the long run. More so, one percent increase in CUSEXC, reduces INFL by $.0005504 \%$ in the long run, this also shows a negative effect of CUSEXC on INFL. in the long run. Coefficient is statistically significant confirmed by $\mathrm{P}>|\mathrm{z}|$ which is 0.000 . Overall, the output indicates that the model fits well. The coefficient on INFL in the cointegrating equation is statistically significant. 
Table 7. Johansen Tests for Co-integration

\begin{tabular}{|c|c|c|c|c|c|c|c|}
\hline \hline Rank & Eigen Value & Parm & LL & Trace statistic & $\mathbf{5 \% \text { critical value }}$ & $\mathbf{1 \%}$ critical & Eigen Value \\
\hline \hline 0 & - & 80 & -2147.0927 & 517.0043 & 68.52 & 76.07 & - \\
\hline 1 & 0.99649 & 89 & -2034.0335 & 290.8860 & 47.21 & 54.46 & 0.99649 \\
\hline 2 & 0.98459 & 96 & -1950.5767 & 123.9723 & 29.68 & 35.65 & 0.98459 \\
\hline 3 & 0.86830 & 101 & -1910.0323 & 42.8836 & 15.41 & 20.04 & 0.86830 \\
\hline 4 & 0.65732 & 104 & -1888.6129 & $0.0448^{*} 1^{*} 5$ & 3.76 & 6.65 & 0.65732 \\
\hline 5 & 0.00112 & 105 & -1888.5905 & & & & 0.00112 \\
\hline \hline
\end{tabular}

S o u r c e : author's computation (2018).

Table 7 produced information about the sample, the trend specification, and the number of lags included in the model. The main table contains a separate row for each possible value of $r$, the number of cointegrating equations. When $r=3$, all three variables in this model are stationary. In this study, because the trace statistic at $r=0$ of 517.0043 exceeds its critical value of 68.52 , the null hypothesis of no cointegrating equations are rejected. Similarly, because the trace statistic at $r=1$ of 290.8860 exceeds its critical value of 47.21 , the null hypothesis that there is one or fewer cointegrating equation is also rejected. In the same vein, because the trace statistic at $r=2$ of 123.9723 exceeds its critical value of 29.68 , the null hypothesis that there is two or fewer cointegrating equation is also rejected. The trace statistic at $r=3$ of 42.8836 exceeds its critical value of 15.41 , the null hypothesis that there is three or fewer cointegrating equation is also rejected. In contrast, because the trace statistic at $r=4$ of $0.0448 * 1 * 5$ is less than its critical value of 3.76 , the null hypothesis that there are four or fewer cointegrating equations cannot be rejected. Because Johansen's method for estimating $r$ is to accept as the first $r$ for which the null hypothesis is not rejected, we accept $r=4$ as our estimate of the number of cointegrating equations between these five variables. The "*” by the trace statistic at $r=4$ indicates that this is the value of $r$ selected by Johansen's multiple-trace test procedure. The eigenvalue shown in the last line of output computes the trace statistic in the preceding line. 
Table 8. Granger causality Wald tests - Causality between Taxation and Inflation rate

\begin{tabular}{|c|c|c|c|c|c|}
\hline Equation & Excluded & chi2 & Df & Prob>chi2 & Decision \\
\hline INFL & PPT & 4.8788 & 4 & 0.300 & PPT does not granger - cause INFL \\
\hline INFL & VAT & 4.9351 & 4 & 0.294 & VAT does not granger - cause INFL \\
\hline INFL & CORPT & 3.4087 & 4 & 0.492 & CORPT does not granger - cause INFL \\
\hline INFL & CUSEXC & 4.7069 & 4 & 0.319 & CUSEXC does not granger - cause INFL \\
\hline INFL & ALL & 8.6517 & 16 & 8.6517 & ALL jointly DO NOT granger cause INFL \\
\hline PPT & INFL & 5.362 & 4 & 0.252 & INFL does not granger - cause PPT \\
\hline PPT & VAT & 1350.4 & 4 & 0.000 & VAT granger - cause PPT \\
\hline PPT & CORPT & 154.48 & 4 & 0.000 & CORPT granger - cause PPT \\
\hline PPT & CUSEXC & 294.45 & 4 & 0.000 & CUSEXC granger - cause PPT \\
\hline PPT & ALL & 7565 & 10 & 0.000 & ALL jointly granger cause PPT \\
\hline VAT & INFL & 8.2207 & 4 & 0.184 & INFL does not granger - cause VAT \\
\hline VAT & PPT & 267.66 & 4 & 0.000 & PPT granger - cause VAT \\
\hline VAT & CORPT & 223.09 & 4 & 0.000 & CORPT granger - cause VAT \\
\hline VAT & CUSEXC & 1310.5 & 4 & 0.000 & CUSEXC granger - cause VAT \\
\hline VAT & ALL & 14808 & 10 & 0.000 & ALL jointly granger cause VAT \\
\hline CORPT & INFL & 21.041 & 4 & 0.342 & INFL does not granger - cause CORPT \\
\hline CORPT & PPT & 246.22 & 4 & 0.000 & PPT granger - cause CORPT \\
\hline CORPT & VAT & 1649.4 & 4 & 0.000 & VAT granger - cause CORPT \\
\hline CORPT & CUSEXC & 937.34 & 4 & 0.000 & CUSEXC granger - cause CORPT \\
\hline CORPT & ALL & 38403 & 16 & 0.000 & ALL jointly granger cause CORPT \\
\hline CUSEXC & INFL & 9.3531 & 4 & 0.253 & INFL does not granger - cause CUSEXC \\
\hline CUSEXC & PPT & 257.94 & 4 & 0.000 & PPT granger - cause CUSEXC \\
\hline CUSEXC & VAT & 3414.7 & 4 & 0.000 & VAT granger - cause CUSEXC \\
\hline CUSEXC & CORPT & 137.42 & 4 & 0.000 & CORPT granger - cause CUSEXC \\
\hline CUSEXC & ALL & 37508 & 16 & 0.000 & ALL jointly granger cause CUSEXC \\
\hline
\end{tabular}

S o u r c e : author's computation (2018). 
The results of the five tests for the first equation is shown in the table 8 . The first is a Wald test that the coefficients on the four lags of PPT that appear in the equation for INFL are jointly zero. The null hypothesis that PPT does not Granger-cause INFL cannot be rejected because $\mathrm{Prob}>\mathrm{chi}^{2}$ is 0.300 which is greater than 0.05 , therefore PPT does not granger-cause INFL. Also, the null hypothesis that the coefficients on the four lags of VAT in the equation for INFL are jointly zero cannot be rejected because Prob>chi2 is 0.294 which is greater than 0.05 . So the hypothesis that VAT does not Granger cause INFL cannot be rejected, therefore VAT does not granger-cause INFL. The null hypothesis is that CORPT does not Granger-cause INFL cannot be rejected because Prob> chi2 is 0.492, which is greater than 0.05 therefore CORPT does not granger-cause INFL. More so, the null hypothesis that the coefficients on the four lags of CUSEXC in the equation for INFL are jointly zero cannot be rejected because Prob> chi2 is 0.319 , which is greater than 0.05 . Therefore CUSEXC does not granger-cause INFL. The fifth null hypothesis is that the coefficients on the four lags of all the other endogenous variables are jointly zero. This null hypothesis cannot be rejected in the sense that Prob> chi2 is 8.6517 which is greater than 0.05 , that is that PPT, VAT, CORPT and CUSEXC, jointly, does not Granger-cause INFL. Therefore the null hypothesis is accepted, alternative hypothesis is rejected that is there is no causality between taxation and inflation rate.

Table 9. Direction of Causality between Taxation and Inflation rate

\begin{tabular}{|l|l|c|c|c|l|}
\hline \hline \multicolumn{1}{|c|}{ Equation } & \multicolumn{1}{|c|}{ Excluded } & chi2 & Df & Prob>chi2 & Decision \\
\hline \hline INFL & PPT & 4.8788 & 4 & 0.300 & PPT does not granger- cause INFL \\
PPT & INFL & 5.362 & 4 & 0.252 & INFL does not granger- cause PPT \\
\hline INFL & VAT & 4.9351 & 4 & 0.294 & VAT does not granger - cause INFL \\
\hline INFL & INFL & 8.2207 & 4 & 0.084 & INFL does not granger- cause VAT \\
\hline CORPT & CORPT & 3.4087 & 4 & 0.492 & CORPT does not granger- cause INFL \\
\hline INFL & INFL & 21.041 & 4 & 0.342 & INFL does not granger- cause CORPT \\
\hline CUSEXC & INFL & 4.7069 & 4 & 0.319 & CUSEXC does not granger - cause INFL \\
\hline
\end{tabular}

S o u r c e : author's computation (2018). 
Table 9 showed the results of the causality analysis among petroleum profit tax (PPT), value added tax (VAT) corporate income tax (CORPT), custom and excise duties (CUSEXC) and inflation rate (INFL). The results showed that there was no causality between petroleum profit tax (PPT) and inflation rate (INFL). Also, the findings revealed that the causality did not run from value added tax (VAT) to inflation rate (INFL) and vice visa. That is value added tax did not granger cause inflation rate (INFL), and inflation rate did not granger cause value added tax. Furthermore corporate income tax (CORPT) with the Chi-square statistic (3.4087) and the probability value (0.492), being statistically insignificant, did not granger cause INFL. In the same vein, INFL did not granger cause CORPT. More so, it was revealed that custom and excise duties (CUSEXC) with the Chi-square statistic 4.7069 and the probability value 0.319 , being statistically insignificant, did not granger cause INFL. Also, INFL did not granger caused CUSEXC. Therefore the null hypothesis is accepted, alternative hypothesis is rejected, that is there is no causality between taxation and inflation rate in Nigeria.

\section{SUMMARY AND CONCLUSION}

This study examined the effects of taxation on inflation in Nigeria. It also looked at the direction of causality between taxation and inflation employing the method of Johansen co-integration and the Granger causality tests using data spanning the period 1970-2017. Results showed that PPT has negative significant effect on INFL in Nigeria. VAT, and CORPT also had negative significant effect on INFL. But CUSEXC has the positive insignificant effect on INFL both in the short run and in the long run. All the components of taxation had no causality link with inflation in Nigeria because PPT, VAT, CORPT and CUSEXC, jointly, did not Granger-cause INFL. Conclusively, taxation had negative significant effect on inflation in Nigeria both in the short run and in the long run. Taxation is an effective hedge on inflation. That is taxation had been employed by the government to subside inflation in the country. There is no causality relationship between Taxation and inflation that is taxation did not granger cause inflation in Nigeria and vice visa. It is recommended that taxation should be moderate so that the disposable income of both the individual and corporate organization left after tax fulfillment will breed saving so as to create more investments which will invariably generate more employment opportunities and curb inflation in the country. Government should devise another means of fighting infla- 
tion apart from involvement of taxation so that it will not provoke price instability and standard of living encroachment.

\section{REFERENCES}

Adegbite, T.A., \& Usman, O.A. (2017). Empirical Analysis of the Effect of Taxation on Investment in Nigeria. International Journal in Commerce, IT \& Social Sciences, 4(8), 1-11.

Akhor, S.O., Atu E.C., \& Ekundayo, O.U. (2016). The Impact of Indirect Tax Revenue on Economic Growth: The Nigeria Experience. Igbinedion University Journal of Accounting, 2(08), 62-87.

Anyanwu, J.C. (1997). Nigerian Public Finance. Onitsha: Joanne Educational Publishers.

Atan, J.A. (2013). Tax Policy, Inflation and Unemployment in Nigeria (1970-2008). European Journal of Business and Management, 5(15), 114-129

Bhartia, H.L. (2009). Public Finance. 13th Edn. New Delhi: Vikas Publishing House PVT Ltd.

Engle, R.F., \& Granger, C.W.J. (1987). Co-integration and error correction: Representation, Estimation, and Testing. Econometrica, 5(5), 251-276.

Iniodu, P.U. (1996). Fundamentals of Macroeconomics. Uyo: Centre for Development Studies, University of Uyo.

Johansen, S. (1991). Estimation and Hypothesis Testing of Cointegration Vectors in Gaussian vector Autoregressive Models. Econometrica, 5(9), 1551-1580.

Ojo, M.O. (2000). The role of the Autonomy of the Central Bank of Nigeria (CBN) In Promoting Macroeconomic Stability. Central Bank of Nigeria Economic and Financial Review, 38(1).

Olaoye, C.O. (2016). Determinants of Value added tax, Interest rate, Inflation and Influence on Revenue Generation in Nigeria. International Journal of Economics, Commerce and Management, 4(10), 322-338.

Piana, V. (2001). Inflation Economics. Web Institute.

Thomas, P. (2006). Does the US have a Handle on Inflation? Street Insight. 